\title{
Socio Psychological Counseling: How to Manage Identities?
}

\author{
Philippe Castel, Brigitte Minondo-Kaghad, Marie-Françoise Lacassagne \\ Laboratory of "Socio Psyhoogie et Management du Sport”, University of Burgundy, Dijon, France \\ Email: philippe.castel@u-bourgogne.fr
}

Received December 19 ${ }^{\text {th }}$, 2012; revised January $18^{\text {th }}$, 2013; accepted February $15^{\text {th }}, 2013$

\begin{abstract}
The work presented here is a research carried out into initiatives for returning the long-term unemployed to work. A small case group study based on international expertise in social categorization and communication was conducted in France. This analysis of "long-term unemployment" was done through the consequences for relationships with work with a view to suggesting a suitable remedial approach. The recommended socio psychological counseling is based on reconstructing the professional identity of the long-term unemployed person and implementing this before the return to a supported role that should serve as a springboard towards permanent employment. The results lead to extend this method to other social disabilities.
\end{abstract}

Keywords: Long-Term Unemployment; Socio Psychological Counseling; Social Remediation; Professional Identity

\section{Introduction}

Over the last four decades, unemployment has become an unavoidable reality. This situation is generally a negative experience for the people who go through it. It is a challenging, stressful situation (Borgen \& Amundson, 1987; Prieto, McNeill, Walls, \& Gomez, 2001; Borgen, Admundson, \& McVicar, 2002). Public health studies are beginning to show that there could be links between unemployment and health. International studies focused on mortality and morbidity have shown significant correlations with unemployment (Brenner, 1987). This result also applies in France, where, during the five years from when a period of unemployment starts, the annual mortality rate of men aged 30 to 64 is around three times higher than for employed men of the same age. The risk is doubled for women, and suicide rates show a similar trend (Sermet \& Khlat, 2004). In terms of health, initial research studies into the consequences of a factory closure have reported on the effects on physical and mental health of former employees (Beale \& Nethercott, 1987; Burke, 1984). Unemployed workers seem to experience more colds, viruses (Taylor \& Gavin, 1985), and present more hypertension, high blood pressure, ulcers, heart disease (Kokko \& Pulkkinen, 1998). Unemployed workers are often affected by depression (Archer \& Rhodes, 1993; Lang, 1995) even if this variable seemed to be time dependent (Borgen et al., 2002). In France, this result has been confirmed by case studies comparing active with unemployed persons and cohorts against each other. In fact, premature ageing is observed in the unemployed by 2.7 years for men and 1.2 years for women (Sermet \& Khlat, 2004). In spite of the problems with adjusting the health indicators across the different studies, it seems that in France, more than abroad, unemployment is a greater disadvantage in terms of mortality or actual or perceived health status (Cases \& Cambois, 2004).

Thus, job seekers, by the very fact of being unemployed, are not a pool of active and competent workers who are ready to adapt themselves effectively to the job market. In fact, it is quite common to find people who have been looking for work for over a year, constituting a sub-population of unemployed people dubbed "the long-term unemployed". In France, this sub-population is ten points higher than the average for industrial countries (32\%) and three times that of the USA. Part of this population actually becomes entrenched in their unemployment situation, remaining out of work for over two years.

People in long-term unemployment are managed in a particular way to help them return to work. However, far from being properly integrated all the time, they don't necessarily end in permanent employment. Progressively, they become social "misfits" in their own eyes and the eyes of their managers. It is for these people that we are suggesting socio psychological counseling i.e. a servicewhich adapts socio psychological theories to help workers who are in difficulties. We argued that this type of counseling is particularly relevant for unemployed people because, in a first time, they overall areworkers without job. Some of them could have psychological problems, and would be oriented on clinical specialists, nevertheless, a great part of them, only need to find work. Their statedepends of social and not clinical problems.

\section{Socio Psychological Counseling}

In the socio psychological counseling adapted to long term unemployed people we considered that the human subject functions differently depending on whether he/she operates as a social or personal identity. Tajfel $(1972,1978)$ in fact demonstrated that the concept of the self as a member of a group produces behavior tailored to the enhancement of the group to the detriment of members of other groups (for an example from industry, see Castel \& Lacassagne, 2004; Castel, Lacassagne, \& Viry, 2006).

In initial proposals in the Social Identity Theory (SIT), Tajfel and Turner $(1979,1986)$ suggest a certain number of "identity management strategies” (Ellemers, 1993; Ellemers, Spears, \& Doosje, 2002; Van Knippenberg, 1989) for re-establishing or preserving a positive identity when it is under threat by occupying a disadvantageous position with regard to the group to 
which it belongs (Tajfel, 1978; Tajfel \& Turner, 1986). The SIT (Tajfel, 1981) predicts that the choice of strategy made by the individual depends on his/her personal beliefs in terms of specific factors intrinsic to the inter-group situation (Ellemers, 1993; Hogg \& Abrams, 1988; Tajfel \& Turner, 1979, 1986) i.e. the permeability of barriers, the stability of relationships and the legitimacy of such positions.

The view of the line between "unemployment" and "nonunemployment" greatly depends on the economic climate. If favorable, lines will remain open, and a subject can adopt a personal mobility strategy. Threatened in terms of his/her identity at certain points, he/she can change his/her personal position without changing the position of the group to which he/she belongs. In this way, an unemployed person can look for work and leave the problem group behind.

However, a bad economic climate makes returning to work difficult, with a higher average period of unemployment and an increase in the skills gap between people in and out of work. Barriers are seen to be less permeable, and the position of the unemployed person as more fixed. The intrinsic legitimacy of people in work is also reinforced. In order to maintain a positive self-image when there is no hope of moving into the group occupied by employed people, an unemployed person has two options: Either to adopt a personal identity or change the group to which he/she belongs and adopt an enhanced social identity.

\section{Personal Identity as an Impediment to Employment}

If we refer to the ego-ecology model (Zavalloni, 2007; Zavalloni \& Louis-Guérin, 1984), even if an unemployed person remains confident in some of his/her qualities ("positive self"), he/she cannot, in a society that values the standard of internality (Beauvois \& Le Poultier, 1986), fail to refer to the personal faults and failings that would justify his/her exclusion from the job market ("negative self" on the increase). Given the reduction in resources (financial, relationships...), he/she cannot hope to achieve his ideal, he/she loses his/her aspirations and he/she is less able to get what he/she wants ("positive non-self" on the decrease); in addition to this, as an unemployed person, he/she is seen in a negative light, either as an unlucky person to be pitied or a freeloader ("negative non-self" on the decrease). All these aspects combine to make the subject suffer an identity crisis (Hauchard, Martinez, \& Costalat-Founeau, 2002) resulting, as when individuals retire, in a loss of psychological wellbeing and the emergence of the symptoms of depression (Wang, 2007). This identity-related dynamic leads to psychical problems, and is not an effective route to leaving unemployment. The subject in question loses his/her autonomy and becomes less and less employable.

In spite of social pressure, another exit route consists in changing one's self-image. Confronted with his/her own identity, the subject can find ways of valuing himself/herself. However, this positive image will not stand up to social comparison. The price paid for this identity is therefore isolation, turning in on the self, which is hardly advantageous in terms of finding work

\section{Professional Identity as a Springboard to Work}

Focusing on social identity seems to be an open approach. The subject has a choice of routes-social competition or social creativity.
One strategy for regaining positive self-esteem proposed by Tajfel and Turner (1986) is "social competition". It involves "collective" initiatives aimed at improving the personal position by changing the situation of the group to which the subject belongs. For unemployed people, this strategy would involve taking the place of people working in companies, the latter then finding unemployed. This strategy is not an option, in that it presupposes the existence of complementary groups, where the balance of power is likely to switch. This means that the unemployed group, as it is understood in western society, cannot replace the employed group.

Social creativity would therefore seem to be a more realistic option. In fact, the "social creativity" strategy involves referring to new dimensions, according to which the group to which the subject belongs can differentiate itself clearly from the other group (Lemaine, Kastersztein, \& Personnaz, 1978). It comes in three forms, depending on the nature of the divide (Castel \& Lacassagne, 2005, 2011) that unemployed people see between themselves and others. According to Blantz, Mummendey, Mielke and Klink (1998), where they see that they have opposing values, they are able to re-evaluate the dimensions for comparison by going back to the valency linked to the position of the endo-group. Just as the "Black is beautiful" slogan marked a turning point in the values of Black Americans (Bourhis \& Gagnon, 1994), unemployed people would consider themselves to be in an advantageous position. Here, they can decide to see the status of unemployed person in terms of freedom, leisure time and pleasure... which are all the opposite of the restrictions, stress and fixed working hours... related to the status of employed person. Unemployment can be considered as a "fresh start", an opportunity to devote time to one's self (Kulik, 2001), an opportunity for change (Madonia, 1983) or, in a more radical way, as a "clever" way of life. In this case, unemployed people can consider themselves as opposed to people in employment who are "exploited by the system". This more positive identity can enable the subject to achieve some success in terms of self-esteem, but distances him/her from the world of work at the same time. For people in this kind of situation, returning to work requires an adaptation of individual identity that becomes increasingly difficult.

Another social creativity strategy involves using a category lower on the social scale than one's own as a point of comparison. This involves seeing reality as based on an undercurrent of hierarchical division, and focusing the attention on a category with a lower status, referred to as "subordinated" by Gaertner, Dovidio, Anastasio, Bachman, \& Rust (1993). Of all the social creativity strategies, comparison with lower-status groups is a difficult one, in that social groups immediately below jobseekers are groups that they are in danger of joining, and therefore likely to cause anxiety from the start, which is hardly conducive to strong self-esteem.

A final strategy linked to this type of division involves unemployed people becoming a recognized minority. Nevertheless, this strategy is little seen, as initiatives conducted solely by the unemployed have little chance of being effective. In fact, the unemployed group is not a homogeneous group that brings together people who share the same values or adopt shared behaviour patterns. Its very existence as a minority group has rarely been demonstrated. The Christmas bonus payment obtained in France as of 1998 is a rare, notable exception, and possibly the only one. The unemployed do not have any particular standard for their category to refer to (Masters \& Keil, 
1987) in order to regain positive self-esteem. On the other hand, they can belong to other groups, where members are organized around joint standards, sharing some characteristics with them. This would enable them to rely on a community if they do not belong to the dominant culture. In France, for example, the unemployment rate between 1990 and 1999 went up more in vulnerable urban areas than elsewhere. These areas are mainly populated by immigrants. Relying on the community is therefore a major option for enhancing individual identity.

Patton and Donohue (1998) developed, by carrying out a qualitative survey in Australia, coping strategies leading on a personal well-being of long-term unemployed people and identified 4 strategies. Both of them which consist in keeping busy firstly and re-evaluating career expectations secondly seem to be strategies suggesting that the individual is identified as being able to cope with stress. The two other strategies seem to involve social identification directly. In the mentioned article, "having a positive look" consists in either practicing sporting activities and being identified as a sportsman or sportswoman (belonging to other minority groups) or engaging humanitarian work and being identified as a voluntary helper (focusing the attention on a subordinated category). As to "religious faith" it consists in joining a minority group which differs from the group of unemployed people.

To summarize, according to social categorization theory, an unemployed person does not have the option of adopting the negative image reflected back from belonging to a social group. Thus if he/she doesn't find work, he/she has several options for enhancing his/her identity. $1 / \mathrm{He} /$ she can rely on his/her personal identity: managing to make it a positive one, de-socialises himself/herself, and he/she loses totally on his/her own spontaneous ability to find a way back to work. 2/ He/she can play on his/her social identity, either by entering into social competition, which seems hardly realistic, or adapting the reality using a social creativity strategy to accede to an higher social position. These strategies enable former employees to find social stability, but are a risk to effective job seeking.

We therefore need to try to re-establish a positive identity for these people, facilitating a return to work. It would seem that we first need to do away with the identity as unemployed person and bring back the identity as an employed person.

\section{Counseling and the Professional Identity of the Long-Term Unemployed}

In France, one of the first stages involved in providing for the unemployed is the skills assessment. This involves helping the job seeker to establish his/her career plan, taking account of all the job market can possibly offer. This phase destroys the previous identity as worker and confirms the status as unemployed person. On the contrary, we think it important to preserve the self-esteem of the subject referring to his/her previous professsion. Even if an unfavourable job market means it is not possible to return to work in the same sector and the same role, we would suggest that the subject will be capable of finding alternative solutions if he/she maintains a positive stance. In addition to this, we believe it would be dangerous to set the subject within a reality that holds little promise for the future, when it should actually be a case of helping him/her to build a new universe-one where integration will be possible. Thus, in the very face of the impossibility of finding the same job, the unemployed person must adopt a stance that will enable him/her to take an innovative approach. By preserving the previous identity as employed person, the now unemployed person becomes a respectable person who has lost his/her job for reasons that were not necessarily his/her fault, and who will do everything in his/her power to find the same job again, or find certain aspects of it in a different role. In this way, the unemployed person is no longer the representative of the "unemployed" category, as opposed to the "worker" category, but a member of the world of work (supra-ordinated) who occupies that position at one moment or another. This strategy, known as refocusing on the supra-ordinated group, was devised by Gaertner et al. (1993), and can be found later in the field of supporters when teams lose matches (Bernache-Assolant, Lacassagne, \& Braddock II, 2007; Bouchet, Castel, \& Lacassagne, 2008).

\section{Method}

This mobilization of the professional identity was tested during a University research initiative carried out as part of the PLIE (social plan for integration and employment) at XXX. The XXX is an associative initiative financed by one or more communities and the European Social Fund. Its aim is to help people experiencing serious social and professional difficulties to enter the world of work, a mission that it accomplishes by coordinating and mobilizing various players at local level. In our case, it was an opportunity of involving ourselves with a small group of long-term unemployed people with the widest range of problems in terms of returning to work, so that we might gain a better understanding of any points of resistance and promote the most suitable resources for facing up to them.

\section{Participants}

The participants in this study consisted of seven persons, they were volunteers and their duration under of unemployment range from two at three years.

\section{Procedure}

The initiative took the form of two sessions two months apart lasting three days. The first session, consisting of three phases, was focused on rebuilding professional identity and the second, with two phases, on consolidation and implementation.

The initiative was carried out before a test in a real work situation. There were two course leaders-one to hand out information explaining the theory behind the initiative and the other to manage the group dynamic. In fact, given that the initiative was University-run, it seemed important for knowledge to be considered as a reference tool, even more so because the target audience was considered to be less likely to understand an intellectual vocabulary right from the start. It also seemed important to manage the group dynamic so that it would be positive, and not put anyone at risk.

Phase 1: Anchoring in the professional identity that is to be rebuilt. Participants were encouraged to anchor themselves in a professional identity through two exercises: "Who am I?" and "What is my job?"

"Who am I?” (Kuhn \& McPartland, 1954) is a test that asks the subjects to give a written definition of themselves, initially according to 20 , but more often 12 items, which generally reveals social identity in the first items, then progressively more personal identities. It is therefore particularly suitable for making course members aware of the existence of several identities 
and repositioning the group to the required level of interaction during the period of collaboration.

The fact that "Who am I?" is a psychological test cause some resistance, nevertheless an initial round-table discussion help course members to overcome this initial reaction. In fact, made aware of the aim of the question, an individual knows that he/she will only reveal what he/she wants to. He/she will remain in control. Over and above the round-table, the results from the "Who am I?" test aim members to focus on their jobs and to think about them.

"What is my job?" is an exercise that aims to encourage each course member to "baptise" his professional group, at the same time ascribing an identity to himself/herself and others. After a phase exploring the range of activities relating to each person's job, all the information is condensed down into a single job title. It is adopted when the course member is in $100 \%$ agreement with the details. This public adoption of a job title is considered as the sign of passing a milestone, enabling the course member to move on from the status of job seeker to the status of professional person undergoing change.

To summarize, the subject, called forward as a job seeker, is encouraged to explore all his/her identities through the "Who am I?" test, then he focus on one of them via the "What is my job ?" test, he adopts the new professional identity and finally name it. This conversion of identity makes it possible to begin the phase of exploring the professional identity from a positive stance.

Phase 2: Awareness of professional stereotypes. In order for the professional identity of the course member to be anchored, it has to be put into concrete terms.

Jobs are generally associated with stereotypes. Sales assistants and beauticians are young and pretty. These stereotypes generate expectations from recruiters, but also in Human Resources (HR) managers, and even in the course members themselves. To remove the associations related to different jobs, the group was considered as a point of reference. This involves creating a portrait of the job type starting from the viewpoint of course members not involved in this area of employment. An exercise based on verbal association helps to reveal related images. The most commonly shared features are agreed as points of reference, this collective expression making it possible to measure collective adhesion. This phase, which is generally presented as a game, involves testing the mood of the group, in that it makes people aware of shared points of experience.

Secondly, it is important for any course member who has not joined in with developing the stereotype to become aware of the existence of this social image and the gaps separating him/her from it. How is he/she similar to the prototypical representatives of the jobs discussed? What more can he/she offer? Where does he/she lack? To achieve this, the whole group begins an evaluation of the differences between what the course member reveals of him/her and the stereotype revealed. On the one hand, this involves what he/she lacks i.e. what he/she does not have that the stereotype does, and on the other hand, what he/she does have, in a more or less obvious way, which the stereotype does not. And, even if there are stereotypes associated with the ability of this or that type of person to work (obese people don't work as hard as non-obese people, Arabs are lazy...), it is not a question of going from the characteristics of the person, but rather of the job. During this phase, even if it involves an overtly caricature-based "understanding”, course leaders still need to guide proceedings, especially when reformulating areas of difference. By having overall control over what is said, they can create a standard for intervention that will ensure that any statements made are not hurtful to the target subject.

This stage enables course members to identify areas that they will need to work on. It is not a question of conforming to a stereotype, but of being aware of the gaps between reality and expectation, knowing how to interpret and turn around to transform them to become a benefit.

Phase 3: Bringing employment history into line with professional identity. The aim of this phase is always to reinforce professional identity but by exploring how it has developed over time. This involves reviewing past experience in terms of the previous job held. Course members often tend to list training and professional history. In this public explanation phase, the group ask each other questions and identify problem issues and, in doing this, they can help the course members to extricate the background logic. Obvious inconsistencies are often revealed when the course member gives his/her explanation; however, this work often reveals a number of problem issues in terms of the search for employment. Based on the fact that any recruitment procedure is competitive, and knowing that any atypical aspects - whether positive or negative-are reasons for rejecting a job application right from the start, these elements have to be presented as an asset in terms of the world of work.

These points are worked on further to emphasize the positive features they might represent, which enables the course member to take these contentious aspects on board, absorb them into his/her overall profile and finally integrate them into his/her professional identity. This in-depth review carried out in a group setting and taking input from other course members, can lead to deconstructing certain phases of experience and building them into new ones.

At the end, they create a Curriculum Vitae (CV) that is a better reflection of the consistency of their employment history. It is not a case of scrupulously following a time line, but of showing sequences of experience to demonstrate the overall coherence of the whole.

Work is also done on format, style, presentation, layout...to promote the assumption of the professional identity, where the concrete $\mathrm{CV}$ becomes something that the subject has created personally, and in which he/she recognises himself/herself.

To summarize, the CVs that the course members take away with them are the result of a process of appropriation and the concrete expression of their true professional identity-in which they fully recognise themselves.

Phase 4: How to present yourself when interacting. Course members need to be made aware of the rules governing verbal interaction. The course leaders present the Ghiglione co-construction model (1986). And they implement it through the covering letter, which encourages review without any improvisation, then through simulated interviews, where there is a greater opportunity for improvisation.

The letter concerning motivations. Once the professional identity has been developed, we need to empower course members to use it to their advantage in real situations. The covering letter, which allows time for consideration before actually entering into communication, offers the first opportunity for learning. In fact, if we see the elements of professional identity as potential content, the rules of communication structure the way to introduce one self. In analysing the letter, emphasis is put on respecting the status of the addressee (position chosen in 
the heading, form of address at the start of the letter, forms of politeness, type of sign-off) and to the aspects of the job history that might impress the addressee. This work aims to make people aware that the covering letter is not just a routine matter, but constitutes a real communication tool, giving the applicant a chance to highlight what he/she can bring to the table.

This work on the covering letter enabled course members to move from the role of poor ignorant job seeker to the role of a professional person with skills to satisfy, which might encourage the recruiter to choose him/her. In other words, this first stage involving work on the covering letter aims at making the course member think of himself/herself as a potential resource when in professional interaction with others.

The job interview. For the course member, the job interview is the prime opportunity to put forward his/her professional identity. Seated opposite the interviewer, who is in the dominant position (Brown \& Fraser, 1979), he/she has to "sell" his/her skills. Nevertheless, they have to deep the understanding of the rules governing verbal interaction in the special situation that is recruitment. Course members gain an awareness of the limits and importance of their role in the interview: follow a procedure dictated by the other person, but remain the master of their own skills.

\section{Results}

\section{Who I am}

\section{Spontaneous expression}

- One individual gave his last name and first name, age, education, previous employment and current status;

- Another individual, an interview specialist, started by listing his/her personal qualities, family details, life history and current status as "job seeker”;

- Another one spoke about his/her culture, reasons for being in France and qualifications;

- $\ldots$

\section{Identity classification}

- Personal identity (sociable, fear of failure...);

- Professional identity (beautician, stores person, engineer);

- Gender and generational identity(Man/Woman, Young/ Old);

- Cultural group (Moroccan, Belgian, Algerian...).

"What is my job?"

Title for professional identity

- Building trade engineer;

- Canteen employee;

- Computer developer;

- Administrator;

- Social economy and family advisor;

- Multi-service employee;

- Beautician.

\section{Awareness of Professional Stereotypes}

\section{Summary of work with one member:}

Mrs X, aged 45, describes herself as a beautician. The stereotype for this job refers to a young, pretty woman, to such an extent that HR experts felt it appropriate to ask Mrs X to leave that job behind and retrain to do a job more suited to her age-_"phone sales person". Yes, Mrs X is no longer 20 years old, but if she is not "pretty" as in the first flush of youth, she is elegant nevertheless, and has no intention of hiding her face in order to do a job. In addition to this, she likes to work in "body care”, and refuses to give this up. Aware of the stereotype, which is presented as an absolute truth, Mrs X tried to break through the barrier to the job interview, sending photos of herself ten years younger and leaving out her date of birth on applications. She didn't get a job.

The benefit of maturity is experience. Mrs X has a solid base of experience that cannot be obscured by her age, but she is not drawing attention to this asset. In fact, Mrs X has worked in a number of countries (Algeria, Canada) and has special skills. She could therefore help a beauty salon to extend its range of services. The second benefit ascribed to maturity is a serious approach. This quality could contribute to the professional image of a salon, and also give the salon access to a population of young people whose parents need to be brought on board first. Finally, it can also give the salon access to an older population, appreciating that there is no need to compare themselves against impossible standards.

Finally, outside jobs offered by salons, Mrs X could help an ageing population (as of 1 January 2007, 10.3 million people were aged 65 or over i.e. $16.2 \%$ of the population) to stay "beautiful" in their own eyes.

\section{How to Employment History into Line with Professional Identity}

\section{Summary of work with one member}

Mrs Y gives an actual photocopy of her CV. This is the CV she usually adapts when responding to job vacancies. After an initial phase with comments from all sides ("You had long hair", "Ah! You've got a land line, mobile and email-you're well sorted"), the course leaders refocused the discussion on the suitability of the CV and the professional identity of the person as everyone has understood it. In this way, a photo that the candidate chose for its aesthetic value shows a hairstyle that is hardly appropriate, which a course member points out ("You look like you're going to a night club!”). The heading only includes the candidate's contact details, giving no information about civil status. The only item relating to civil status is given implicitly, and is relegated to the final section under "additional information" as "Based in France since 2007_residence permit (valid 10 years)". Putting this information at the end can only be a problem for the recruiter. He/she cannot but be suspicious about her status and whether her position in France is stable. It shatters the image of an engineer and evokes one of the world of immigrants, represented in social terms as low-status workers, and even the world of people with no official papers. The positioning of this information also casts a shadow over the rest of her CV. Mrs X was born in Algeria, did all her studies there and acquired serious levels of professional experience, occupying a number of posts in line with her career trajectory. By hiding her ethnic origins, she makes her professional experience seem a little vague, the cities she mentions are not recognised and can seem made up, hence the questions put by the group: "Where's that?", "So you were an in-house engineer in Algeria? Do you really get women engineers over there?” These innocent questions are a sign of the suspicions that this CV will certainly arouse in recruiters, who probably won't know anything about the businesses referred to. In the same way, the school and University course details refer to titles that people are not familiar with ("Baccalaureate +2 , preparatory"). 
Finally, the group observed that the section entitled "My career goals", which is meant to be a strong statement, merely referred to inconsequential matters totally unrelated to the aspirations previously described. With the content problems solved, the course leaders refocus the group onto finding format errors (presence or systematic absence of dashes, keeping to the same format, use of the substantive or infinitive...).

\section{How to Present Yourself When Interacting}

\section{First Stage}

In most cases, the letters would be just like a conventional one. The course members mainly focused on formal aspects, starting from an assumption that they were not suitably skilled. This meant that they wrote a minimal amount, often containing "errors" in the spelling, and syntax too, sometimes making the letter meaningless. The people who were most comfortable with this type of exercise produced highly precise and accurate letters, but which said nothing.

\section{Second Stage}

The course members try to "make them take on board". They tried to adapt their understanding of their employment history to the inferences that the recruiter might make. This work, conducted on a more individual basis, was done outside the session, with the course member ultimately putting his "finished" letter up for discussion by the group. In this discussion, the rest of the group make comments from the point of view of the recruiter, making it possible to make improvements in terms of what that individual had revealed about himself/herself since the start of the initiative.

\section{The Job Interview}

During the first few sessions, the interviews had a tendency to move away from the pact of communication. For example, one individual assumed the role of guiding the interview by asking questions right away ("What time does work start?"); another individual gave a cutting response, almost accusing the recruiter ("You haven't read my file properly, it's written in my CV!"); another one questioned the legitimacy of the investigations made by the interviewer ("you don't need to ask me about my private life”). In group discussions, nobody noticed these infractions of the rules of conversation right away, which leads to the conclusion that these are not the result of "individual pathologies" but are in fact the collective norm.

Over the next few sessions, the course members followed these imperatives, but totally jettisoned the relevant information about their past professional experience.

The next exercises went on to reinstate the importance of their professional identity, whilst still following the roles dictated by the interview situation.

\section{General Conclusion}

Unemployment changes financial resources and removes the individual from his/her group of reference. In other words, it renders him/her poor and de-socializes him/her. In fact, regardless of the role previously occupied, losing job means losing a major element of what supports identity, and makes the person "unemployed". As soon as he/she becomes unemployed, an individual becomes vulnerable, and has to find a positive identity. When he/she does this, the ways of getting out of the situa- tion, adopted spontaneously, only serve to move him/her further away from the world of work. Some kind of help therefore seems necessary, but needs to avoid the same stumbling block. In most cases, the unemployed person will have worked before, and we suggest that his/her previous professional identity needs to be reanimated before he/she considers how to adapt himself/herself better to the job market. In fact, it appears that only an individual who is "sure of himself/herself" i.e. who have a positive social identity, will be capable of developing into a new type of role. We have therefore proposed an initiative based on psycho-social counseling, which we have tested on a population known for its problems, such as the long-term unemployed, whichever country they might come from (Dubé \& Dionne, 2005). The first phase involved labeling the individual by their job. It was a kind of professional "baptism", giving them a social identity traceable by and acceptable to other people. Through comparison with a stereotype, the second phase involved giving substance to the current professional identity. Exploring the past, the third phase (studies, professional experience) gave a history to the professional identity-in the concrete form of a CV. The final phase (immersion in the real world) involved exposing the identity and making it public (baptism of fire) in the covering letter, followed by the interview. Initiatives conducted in a class setting actually produced the positive results expected. Course members rediscovered an enhanced professional identity, which they maintained throughout the sessions, and which some of them put to the test. This took the form of taking personal initiatives, such as applying for jobs resulting from remedial work or training designed to take them back to their actual level of qualification, and not designed for people with problems. Nevertheless, to achieve maximum effectiveness from the initiative, it would have been necessary to consolidate counselling with a follow-up period when they were at working again, which this institution-led initiative did not allow. In fact, in this initiative, getting someone into a role equivalent to the one the course member had before was only meant to act as a springboard to permanent employment. Finally, it should be emphasized that the proposed counseling still remains within the scope of social remediation and not personal remediation.

This method might be limited in terms of cases involving psycho-pathology. In fact, it is only designed for long-term unemployed people with social problems i.e. who have experienced a hiccup in their job history that is no fault of their own, or job seekers belonging to populations suffering from discrimination (racism, ageism, sexism). In such cases of social remediation, even if the job histories of some "cases", being social in construction, necessarily have psychological repercussions, it would seem preferable to establish a contractual framework from social identity.

\section{Acknowledgements}

We thank the European Social Fund who has financially supported the present research.

\section{REFERENCES}

Archer, J., \& Rhodes, V. (1993). The grief process and job loss: A cross-sectional study. British Journal of Psychology, 84, 395-410. doi:10.1111/j.2044-8295.1993.tb02491.x

Beale, N., \& Nethercott, S. (1987). The health of industrial employees 
four years after compulsory redundancy. The Journal of the Royal College of General Practitioners, 37, 390-394.

Beauvois, J.-L., \& Le Poultier, F. (1986). Norme d'internalité et pouvoir social en psychologie quotidienne. Psychologie Française, 31, 100-108.

Bernache-Assollant, I., Lacassagne, M.-F., \& Braddock II, J. H. (2007). Basking in reflected glory and blasting: Differences in identity management strategies between two groups of highly identified soccer fans. Journal of Language and Social Psychology, 26, 381-388. doi:10.1177/0261927X07306981

Blantz, M., Mummendey, A., Mielke, R., \& Klink, A. (1998). Responding to negative social identity: A taxonomy of identity management strategies. European Journal of Social Psychology, 28, 697729.

doi:10.1002/(SICI)1099-0992(199809/10)28:5<697::AID-EJSP889> 3.0.CO;2-\#

Borgen, W. A., \& Admundson, N. E. (1987). The dynamics of unemployment. Journal of Counseling and Development, 66, 180-184. doi:10.1002/j.1556-6676.1987.tb00841.x

Borgen, W. A., Admundson, N. E., \& Mcvicar, J. (2002). The experience of unemployment for fishery workers in Newfoundland: What helps and hinders. Journal of Employment Counseling, 39, 117-126. doi:10.1002/j.2161-1920.2002.tb00843.x

Bouchet, P., Castel, P., \& Lacassagne M.-F. (2008). Proposition d'un cadre d'analyse des relations intergroupes conflictuelles potentiellement violentes et discriminatoires dans le spectacle sportif. Recherches en Communication, 30, 111-127.

Bourhis, R. Y., \& Gagnon, A. (1994). Les préjugés, la discrimination et les relations intergroupes. In: R.-J. Vallerand (Ed.), Les fondements de la psychologie sociale (pp. 708-773). Montréal: Gaëtan Morin Editeur.

Brenner, M. H. (1987). Economic change, alcohol consumption and heart disease mortality in nine industrialized countries. Social Science and Medicine, 25, 119-132. doi:10.1016/0277-9536(87)90380-7

Brown, P., \& Fraser, C. (1979). Speech as a marker of situation. In K. R. Scherer \& H. Giles (Eds.), Social markers in speech (pp. 33-62). Cambridge: Cambridge University Press.

Burke, R. J. (1984). The closing of Canadian admiral: Correlates of individual well-being sixteen months after shutdown. Psychological Reports, 55, 91-98. doi:10.2466/pr0.1984.55.1.91

Cases, C., \& Cambois, E. (2004). Chômage et santé: Un enjeu pour les statistiques publiques. Revue d'Epidémiologie et de Santé Publique, 52, 409-413. doi:10.1016/S0398-7620(04)99076-1

Castel, P., \& Lacassagne, M.-F. (2004). Intergroup processes and management. Pakistan Journal of Social Sciences, 2, 53-56. doi:pjssci.2004.65.69

Castel, P., \& Lacassagne, M.-F. (2005). Les partitions discriminantes dans la négociation du contrat de communication. Bulletin de Psychologie, 58, 299-306. doi:10.3917/bupsy.477.0299

Castel, P., \& Lacassagne, M.-F. (2011). Contrat de communication et partitions sociales. In P. Castel, E. Sales-Wuillemin, \& M.-F. Lacassagne, (Eds.), Psychologie sociale, Communication et Langage (pp. 20-34). Paris: De Boeck.

Castel, P., Lacassagne, M.-F., \& Viry, C. (2006). Biais de discrimination et statut social: Une étude de terrain sur les relations intergroupes. Le Travail Humain, 69, 305-315.

doi:10.3917/th.694.0305

Dubé, V., \& Dionne, C. (2005). Toujours à la recherche d'un emploi, L'emploi et le revenu en perspective. Catalogue de Statistique du Canada, 6, 10-15.

Ellemers, N. (1993). The influence of socio-structural variables on identity management strategies. European Review of Social Psychology, 4, 27-57. doi:10.1080/14792779343000013

Ellemers, N., Spears, R., \& Doosje, B. (2002). Self and social identity. Annual Review of Psychology, 53, 161-186.

Gaertner, S. L., Dovidio, J. F., Anastasio, P. A., Bachman, B. A., \& Rust, M. C. (1993). The common ingroup identity model: Recategorization and the reduction of intergroup bias. European Review of Social Psychology, 4, 1-26. doi:10.1080/14792779343000004
Ghiglione, R. (1986). L'homme communiquant. Paris: Armand Colin.

Hauchard, D., Martinez, N., \& Costalat-Founeau, A.-M. (2002). Vieillissement et dynamique identitaire: Une analyse égo-écologique. Pratiques Psychologiques, 3, 79-100.

Hogg, M. A., \& Abrams, D. (1988). Social Identifications. London: Routledge.

Kokko, K., \& Pulkkinen, L. (1998). Unemployment and psychological distress: Mediator effects. Journal of Adult Development, 5, 205-217.

Kuhn, M. H., \& Mcpartland, T. S. (1954). An Empirical Investigation of self-attitude. American Sociological Review, 19, 68-76. doi: $10.2307 / 2088175$

Kulik, L. (2001). Impact of length of unemployment and age on jobless men and women: A comparative analysis. Journal of Employment Counseling, 38, 15-28. doi:10.1002/j.2161-1920.2001.tb00489.x

Lang, S. S. (1995). People unemployment, on welfare are at risk for depression. Human Ecology, 23, 23-30.

Lemaine, G., Kastersztein, J., \& Personnaz, B. (1978). Social differentiation. In H. Tajfel (Ed.), Differentiation between social groups. studies in the social psychology of intergroup relations (pp. 269-300). London: Academic Press.

Madonia, J. F. (1983). The trauma of unemployment and its consequences. Social Casework: The Journal of Contemporary Social Work, 23, 482-488.

Masters, J. C., \& Keil, L. J. (1987). Generic comparison processes in human judgment and behavior. In J. C. Masters, \& W. P. Smith (Eds.), Social comparison, social justice and relative deprivation (pp. 11-54). Hillsdale, NJ: Lawrence Erlbaum.

Patton, W., \& Donohue, R. (1998). Coping with long term unemployment. Journal of Community and Applied Social Psychology, 8, 331-343.

doi:10.1002/(SICI)1099-1298(1998090)8:5<331::AID-CASP456>3. $\underline{0 . \mathrm{CO} ; 2-6}$

Prieto, L. R., Mcneill, B. W., Walls, R. G., \& Gomez, S. P. (2001). Chicans/os and mental health services: An overview of utilization, counselor preference, and assessment issues. The Counseling Psychologist, 29, 18-54. doi:10.1177/0011000001291002

Sermet, C., \& Khlat, M. (2004). La santé des chômeurs en France: Revue de littérature. Revue d'Epidémiologie et de Santé Publique, 52, 465-474. doi:10.1016/S0398-7620(04)99082-7

Tajfel, H. (1972). Social categorization. In S. Moscovici (Ed.), Introduction à la psychologie sociale (pp. 30-37). Paris: Larousse.

Tajfel, H. (1978). Differentiation between social groups: Studies in the social psychology of intergroup relations. London: Academic Press.

Tajfel, H. (1981). The attributes of intergroup behavior. In H. Tajfel (Ed.), Human groups and social categories (pp. 228-253). Cambridge: Cambridge University Press.

Tajfel, H., \& Turner, J. C. (1979). An integrative theory of intergroup conflict. In W. G. Austin, \& S. Worchel (Eds.), The social psychology of intergroup relations (pp. 33-37). Monterey, CA: Brooks/Cole.

Tajfel, H., \& Turner, J. C. (1986). The social identity of intergroup behavior. In S. Worchel, \& W. G. Austin (Eds.), Psychology of intergroup relations (pp. 7-24). Chicago, MI: Nelson Hall.

Taylor, M., \& Gavin, J. (1985).An examination of individual and community adaptation to Atlantic fishing industry reductions using the "Taylor Model". Montreal: Concordia University.

Van Knippenberg, A. (1989). Strategies of identity management. In J. P. Van Oudenhoven, \& T. M. Willemsen (Eds.), Ethnic minorities: Social psychological perspectives (pp. 59-76). Amsterdam: Swets \& Zeitlinger.

Wang, M. (2007). Profiling retirees in the retirement transition and adjustment process: Examining the longitudinal change patterns of retirees' psychological well-being. Journal of Applied Psychology, 92, 455-474. doi:10.1037/0021-9010.92.2.455

Zavalloni, M. (2007). Ego-écologie et identité: Une approche naturaliste. Paris: Presses Universitaires de France.

Zavalloni, M., \& Louis Guerin, C. (1984). Identité sociale et conscience: Explorations égo-écologiques. Revue Internationale de Psychologie Sociale, 1, 173-187. 